\title{
IS THERE A DECLINE IN TEACHING ETHICS IN US BUSINESS SCHOOLS?
}

\author{
James P. Beaghan, Central Washington University, WA
}

\section{ABSTRACT}

With recent financial scandals at Global Crossing, Enron and WorldCom, there has been an increased level of debate concerning ethical decision making among business leaders in America and abroad. This debate has been accompanied by an increased expectation that US business schools give more emphasis to ethics in their business curriculum at both the undergraduate and graduate levels. Over the last ten - fifteen years there has also been considerable debate within business schools over whether ethics should be covered as a separate course (required or elective), a component of all core business courses, a component of all business courses, or a combination. There also seems to be a lack of consensus over whether ethics can be taught, and whether the coverage of ethics in the business curriculum will have an effect on behavior after graduation. With AACSB mandating the coverage of ethics in business curriculum for member schools, business school administrators and faculty have shown considerable latitude in the coverage of this topic. This paper looks at the coverage of ethics in the business school curriculum of two universities: one a public university, one a private religious university, as well as several universities cited in recent research articles. A random sample of students in business courses at the two US universities have been surveyed during 2007 to determine the extent to which ethics is covered in the course, with the results compared to the syllabus for each sampled course to determine whether the intended coverage of ethics by the course instructors differs 
from actual coverage in the course. The results of the survey are compared to recently published studies on the coverage of ethics at several universities to determine current trends on the level of coverage of ethics in their business school curriculum, and whether the teaching of ethics is on the decline in business schools.

\section{INTRODUCTION}

With recent financial scandals at Global Crossing, Enron and WorldCom, there has been an increased level of debate concerning ethical decision making among business leaders in America and abroad. This debate has been accompanied by an increased expectation that business schools give more emphasis to ethics in their business curriculum at both the undergraduate and graduate level.

Over the last ten - fifteen years there has also been considerable debate within business schools over whether ethics should be covered as a separate course (required or elective), a component of all core business courses, a component of all business courses, or a combination. There also seems to be a lack of consensus over whether ethics can be taught, and whether the coverage of ethics in the business curriculum will have an effect on business student behavior after graduation.

With AACSB mandating the coverage of ethics in the late 1980's business curriculum for member schools, business school administrators and faculty have shown considerable latitude in the coverage of this topic in business courses. This paper looks at the coverage of ethics in the business school curriculum of two universities: one a public university, one a private religious university, as well as several universities cited in several recent research articles.

A random sample of students in business courses at the two US universities have been surveyed during 2007 to determine the 
extent to which ethics is covered in the course, with the results compared to the syllabus for each sampled course to determine whether the intended coverage of ethics by the course instructors differs from actual coverage in the course.

The results of the survey are compared to recently published studies on the coverage of ethics at several universities with conclusions made about a possible trend involving the de emphasis of teaching ethics in business school curriculum, while university business school administrators give lip service to the AACSB mandate that ethics should be a part of member school business curriculum at both the graduate and undergraduate levels.

\section{LITERATURE REVIEW}

\section{COVERAGE OF ETHICS IN BUSINESS SCHOOLS}

Schoenfelds, McDonald, and Youngblood (1991) indicate significant coverage of ethics at over $90 \%$ of the business schools in their study, with McDonald (2007) reporting that the number of stand alone ethics courses increasing by $500 \%$ since 1998 with one third of business programs requiring course work in ethics. While Alsop (2006) reports that some business schools are beginning to require stand alone ethics courses, Farnsworth (2003) states that ethics should be a required course to prepare students for the ethical dilemmas of the workplace.

In a recent article in the Denver Post (May 20, 2007) it was reported that despite a rapid increase in the teaching of ethics in U.S. business schools after Enron, a recent informal poll of business school deans shows that faculty and administrative commitment in teaching ethics is once again declining. USA Today (Jan 2007) also reports that ethics courses in business schools has declined in the last two 
years, while the Denver Business Journal (2003) states that many U.S. business schools have ethics cut or diluted ethics courses.

Shannon (1997) reports that there is a greater focus on teaching ethics at private religious university schools of business than at public university schools of business, and also at non - AACSB accredited schools of business in comparison to AACSB accredited schools of business.

\section{CAN ETHICS BE TAUGHT?}

The Economist (May 12, 2007) reports that it is not clear that ethics can be taught, and that building a common code of ethics is an unlikely prospect, while Jennings (1999) states that with the increase in disdain for business and capitalism in many liberal arts schools, and the increase in emphasis on multiculturalism, political correctness, radical feminism, and postmodernism on college campuses, business students are not being taught the moral foundations of ethical business practices.

The Christian Science Monitor (2007) reports that although business ethics as a stand alone course of study has grown rapidly over the past ten - fifteen years, people who coach business executives on ethics say the academic approach to teaching ethics does not work, and that "ethical action" requires an "ethical culture" in the workplace. The New York Times (2002) also reports that while ethics courses can help students who are "well intentioned," they will "flounder" when they go to work for companies who emphasize results over honesty.

While the Gautski (1998) study shows that students enhance their ability to recognize ethical issues in business after completing a business course, Burns and Cohen (2006) cite Fr. John Jennings, President of the University of Notre Dame, stating that, "while rules can be taught, the deepest kind of ethics requires something deeper," 
and that Davis (1991) states that, "formal ethics training is not likely to be the dominant factor in the development of ones perceptions of ethical behavior."

\section{STUDENT ATTITUDES ON ETHICS IN BUSINESS SCHOOL}

\section{CURRICULUM}

Warren (2006) cites a Chen-Fong Wu (2003) study that reports that business school students ethical decision making is still sub - optimal, while The Wall Street Journal (June 19, 2007) reports that a London Business School offered ethics courses as electives with modest student response, and that some professors are reluctant to teach about ethics and social responsibility.

Pizzolatto (1996) reports that business school students feel that their college instruction has prepared them to deal with ethical issues on the job, while Stewart (1996) states that business majors think it is important to teach ethics, and prefer to have it integrated into a number of courses, with female students attaching more importance on teaching ethics than males.

Crane (2004) reports, that MBA students support a required ethics course in business schools. The New York Times (2003) reports that only $22 \%$ of MBA students think their business schools are doing an adequate job in preparing them to handle ethical conflicts on the job.

\section{BUSINESS SCHOOL FACULTY ATTITUDES TOWARD TEACHING ETHICS}

Godson (2007) reports that AACSB cites faculty apathy toward teaching ethics while The Washington Post (2002) reports that business school professors feel that AACSB requirements should be more "straightforward" about whether MBA students should be 
required to take at least one ethics course, while debating among themselves what constitutes ethical behavior.

Beggs (2007) reports that business school faculty recommend that external forces, such as legislation, are a better solution to unethical behavior in the workplace, rather than ethics education, while Hughes (2006) reports that business school professors are emphasizing ethics more as a part of their instruction.

\section{RESEARCH METHOD}

One hundred forty two business students in six randomly selected courses taught during 2007 at two universities were included in this study. A research instrument/questionnaire was developed and administered to business students at both universities. Research questions included differences in student expectations about the coverage of business ethics in their business and accounting courses, as well as the current levels of coverage of business ethics in each course. A series of Likert questions on a five point scale, ranging from (1) strongly agree to (5) strongly disagree were included in the questionnaire to assess business and accounting student attitudes towards the expectation of the coverage of business ethics in their courses, as well as the current level of coverage of business ethics in each course.

The results of the survey were then analyzed for each question using the means and one way analysis of variance (ANOVA) to determine whether any significant differences in student attitudes toward the expectation of coverage of business ethics and the current level of coverage of business ethics in their business and accounting courses differed for students at the two universities. The results of the survey were then compared with the syllabi for each course to determine the instructors intended coverage of business ethics in each course at the two universities, and then compared to trends on the 
coverage of ethics in business schools cited in current literature. Conclusions were made, concerning whether teaching business ethics is currently on the decline in business schools.

\section{RESULTS}

The results of the survey administered to students in business courses at two universities, one a private religious university and one a public state supported university, show significant differences in both the coverage of business ethics in their courses, as well as their preference for additional coverage of business ethics as either a required or elective course in their business school curriculum.

Students at the private religious university strongly agreed $(68 \%)$ or agreed $(29 \%)$ that "business ethics was a frequent topic in this course," while students at the public state supported university either agreed $(39 \%)$ or neutral $(31 \%)$ on this issue. Students at the public university generally agreed (35\%) that they would "like more coverage of ethics in this course," while students at the private university were neutral (62\%), probably because business ethics was a frequent topic currently being covered in their course (see EXHIBIT).

Students at both universities tended to agree that they would "like more coverage of business ethics in other courses" within their business school curriculum. Students at the private university tended to strongly agree $(62 \%)$ or agree $(24 \%)$ that "Business Ethics should be a required course," while students at the public university also tended to agree $(38 \%)$. Students at both universities tended to agree that "Business Ethics should be an elective course" in their business school curriculum. The responses of male and female students at both universities were essentially the same in this study (see EXHIBIT).

In terms of the intended level of coverage of business ethics by instructors in the selected business courses at the two universities, 
there were significant differences, with the syllabus for the selected courses at the public university not listing ethics as either an intended topic or reference chapter, while the syllabus at the private religious university did specifically list ethics as an intended topic and referenced chapter, and included a written assignments on ethics.

While the private religious university does not have required Business Ethics course, it does have an elective Business Ethics course in its business school curriculum. The public university has neither a required nor an elective Business Ethics course in its business school curriculum.

\section{DISCUSSION AND CONCLUSION}

With the recent scandals in the business community, there appears to be universal agreement that there needs to be an improvement in ethical decision making within the private sector. At the same time there is a diversity of opinions over the most effective methods of bringing about more ethical decision making in the workforce, and whether ethical behavior can be taught, The Economist (May 12, 2007), with The Christian Science Monitor (2007), Burns \& Cohen (2006), with Davis (1991) questioning whether formal ethics training is likely to be the dominant factor in its development of ethical behavior.

While many consider business schools as an appropriate place to train future business leaders ethical decision making, AACSB has mandated the coverage of ethics in business school curriculum for member schools since the late 1980's, Farnsworth and Kleiner (2003). Since then, among faculty and business school administrators, there has been considerable debate over how ethics should be covered, and what constitutes ethical behavior, with the AACSB offering little in the way of straightforward requirements, Washington Post (2003). 
With faculty apathy toward teaching ethics being cited, Goodson (2007) and Beggs (2007) report that many business school faculty feel that external forces such as legislation are a better solution than teaching ethics to unethical behaviors in the workplace. The results of this survey are consistent with much of the literature concerning student attitudes on the importance of the coverage of ethics in business school curriculum, and the intensity of coverage of ethics that they are currently experiencing in their business courses.

While students at the private religious university tend to agree or strongly agree that Business Ethics should receive more intense coverage, students at the public state supported university either agreed or were neutral on this position, consistent with the results reported by Simmons (1997). Students at the private university also tended to prefer a required business ethics course more than students at the public university, consistent with Crane (2004). There were also differences in the intensity of coverage of business ethics by faculty at the two schools of business, with much more intensity of coverage by faculty at the private religious university than the public state university, consistent with Goodson (2007).

In summary, the results of this study are consistent with current research indicating that teaching ethics in business school curriculum maybe on the decline in public universities, and with AACSB accredited schools of business, while private and non AACSB accredited universities are showing increased intensity of coverage of business ethics in their business school curriculum, Simmons (1997).

Additional longitudinal research will be necessary before we can conclude whether a de emphasis of intensity of coverage of business ethics is taking place in public AACSB accredited business schools, as reported in this study and supporting research literature, and whether this is part of a long term trend. 


\section{REFERENCES}

Alsop, R., (2007). Talking b-school: Why teaching of ethics continues to be lacking. The Wall Street Journal (Eastern Edition), June 19, pg. 7 .

Alsop, R., (2006). Business ethics education in business schools: A commentary. Journal of Management Education, Feb., 30, 1, 11-15.

Beggs, J.M., and Dean, K., L. (2007). Legislated Ethics or Ethics Education: Faculty Views in the Post-Enron Era," Journal of Business Ethics, 2007, pp 15-37.

Browning, L., "Ethics Lacking in Business School Curriculum, Students Say in Survey", New York Times (Late Edition - East Coast), May 20, 2003, pg C3.

Crane, F. G., "The Teaching of Business Ethics: An Imperative at Business Schools", Journal of Education for Business, (January/February 2004), (79)3, pp. 149-151.

Burns, G., and Cohen, J., S., "Can You Teach Ethics? Business School Classes Take a Swing at it", Knight Ridder Tribune News Service, June 19, 2006, pg. 1.

Davis, J., R., and Welton, R., F., "Professional Ethics: Business Students' Perception", Journal of Business Ethics, June 1991, (10)6, pg 451.

Etzioni, A., "When it Comes to Ethics, B - Schools Get an F," The Washington Post, August 4, 2002, pg B 4.

Farnsworth, J.R., and Kleiner, B.H., "Trends in Ethics Education at US Colleges and Universities," Management Research News, 2003, (26)2-4, pg 130 -140. 
Gautschi III F., H., and Jones, T., M., "Enhancing the Ability of Business Students to Recognize Ethical Issues: An Empirical Assessment of the Effectiveness of a Course in Business Ethics", Journal of Business Ethics, January 1998, (17)2, pp 205-276.

Godson, N., "Note to Business Schools: Practice What You Teach", Baylor Business Review, Spring 2007, (25)2, pp 48-49.

Hughes, B., "Professors Focus on Ethics in Class, Vandy Dean Says", Knight Ridder Tribune Business News, September 15, 2006, pg 1.

Jennings M., M., "What's Happening in Business Schools?", Public Interest, Fall 1999, 137, pp 25-33.

MacDonald, J., G., "Can Business Ethics be Taught?; Post-Enron, Business Schools are boosting ethics courses. But Critics Say Book Learning Won't Change Much", The Christian Science Monitor, March 21, 2007,pg 13.

Moore, P., "Schools Nationwide Trim Ethics Programs, but not in Colorado," The Denver Business Journal, January 10, 2003, (54)25, A12.

Newman, K., "Integrating Business and Ethics; Students Seek More Guidance", Denver Post, May 20, 2007, pg E1.

Prentice, R. (2002). An ethics lesson for business schools. New York Times (East Coast Edition), August. 20, pg A19.

Pizzolatto, A., and Bevill, S. (1996). Business ethics: A classroom priority? Journal of Business Ethics, February, (15)2, pg 153-158.

Schoenfeldt, L., F., McDonald, D., M., and Youngblood, S., A. (1991). The teaching of business ethics: A survey of AACSB member schools. Journal of Business Ethics, March, (10)3, pg 237-241. 
Shannon, R., J., and Berl, R., L., "Are We Teaching Ethics in Marketing?: A Survey of Student Attitudes and Perceptions," Journal of Business Ethics, July 1997, (16)10, pg 1059-1075.

Stewart, K., Felicetti, L., and Kuehn, S., "The Attitudes of Business Majors Toward the Teaching of Business Ethics," Journal of Business Ethics, August 1996, (15)8, pp 913-918.

Warner B., W., and Rosenthall, D., "Teaching Business Ethics - Is it a Lost Course?" International Journal of Management, September 2006, (23)3, pg 679-698.

"Special Report: New Graduation Skills - Business Schools," The Economist, May 12, 2007, (383)8528, pg 80.

"Business Schools Still Lack Ethics," USA Today, Januaury 2007, (135)2740, pg 7 .

\section{About the Author}

James P. Beaghan is Professor of Business Administration at the College of Business, Central Washington University, Des Moines Higher Education Center in Des Moines, Washington State. He can be reached at:BEAGHANJ@cwu.edu 


\section{$\underline{\text { EXHIBIT }}$}

SA= Strongly Agree (1), A= Agree (2), N= Neutral (3), D= Disagree (4),

$\mathrm{SD}=$ Strongly Disagree (5)

1) "Business Ethics" is referenced in
$\begin{aligned} & \text { syllabus this course. } \\ & \text { 1 }\end{aligned}$

2) "Business Ethics" is referenced in $\quad \begin{array}{llllllll}1 & 1 & 2 & 3 & 4 & 5 & 1.898 & .175\end{array}$ syllabi my other courses this term.

3) "Business Ethics" a referenced chapter on syllabus for this course. 
4) "Business Ethics" a topic used infrequently in this course.

5) "Business Ethics" a frequent topic in this course.

6) "Business Ethics" a frequent topic in my other courses this term.

7) I prefer lecture on "Business Ethics" more often in this course. courses this term. 
9) I prefer lecture on "Business

Ethics" less often in this course.

10) I prefer lecture on "Business Ethics" less often in my other courses this term.

11) "Business Ethics" should be a required course in the College of Business Curriculum.

12) "Business Ethics" should be an elective course in the College of Business Curriculum. 